УДК 625.143.5

\title{
ВПЛИВ ТЕРМІНУ ЕКСПЛУАТАЦЇ̈ НА ЗМІНУ ПАРАМЕТРІВ ЖОРСТКОСТІ ПРОМІЖНОГО РЕЙКОВОГО СКРІПЛЕННЯ ТИПУ КБ
}

\author{
Канд. техн. наук В.Г. Вітольберг, В.М. Рева \\ ВЛИЯНИЕ СРОКА СЛУЖБЫ НА ИЗМЕНЕНИЕ ПАРАМЕТРОВ ЖЕСТКОСТИ \\ ПРОМЕЖУТОЧНОГО РЕЛЬСОВОГО СКРЕПЛЕНИЯ ТИПА КБ
}

\author{
Канд. техн. наук В.Г. Витольберг, В.Н. Рева
EFFECT OF LIFETIME TO CHANGE STIFFNESS PARAMETER INTERMEDIATE RAIL FASTENING TYPE KB

Cand. of techn. sciences V.G. Vitolberg, V.M. Reva

Виконано дослідження зміни значення жорсткості рейкових скріплень у прочесі експлуатащії. Визначено фактори, які безпосередньо впливають на зміну значення жорсткості. Визначено необхідні технічні передумови для теоретичних і експериментальних досліджень розв'язання задачі забезпечення необхідної жорсткості рейкових скріплень.

Ключові слова: жорсткість, горизонтальний вигин, кручення рейки, проміжні рейкові скріплення.

Выполнены исследования изменения значения жесткости рельсовых скреплений в проиессе эксплуатации. Определены факторы, которые непосредственно влияют на изменение значения жесткости. Определены необходимые технические предпосылки для теоретических $u$ экспериментальных исследований решения задачи обеспечения необходимой жесткости рельсовых скреплений.

Ключевые слова: жесткость, горизонтальный изгиб, кручение рельса, промежуточные рельсовые скрепления.

The studies of changes in stiffness values intermediate rail fastening type KB in use. The factors that directly affect the change in the value of the horizontal stiffness and torsional rigidity of the rail. The dependences of the change in the stiffness of the intermediate bonding type KB with horizontal bending and torsion of the rail during operation. The necessary technical prerequisites for theoretical and experimental studies of solving the problem of providing the necessary rigidity of rail fasteners.

Keywords: hardness, horizontal bending, twist rail, rail fastening.

Вступ. Просторова жорсткість рейкових опор, яка визначається, зокрема, жорсткістю проміжних скріплень, $є$ одним із головних факторів динаміки взаємодії колії і рухомого складу. Питання динаміки взаємодії, дослідження сил, які впливають на колію з боку рухомого складу, особливо актуальні для умов промислового залізничного транспорту, головні це високі осьові навантаження, підвищена жорсткість ресорних комплектів, криві малих радіусів, рух поїздів у режимі виштовхування.

Аналіз досліджень і публікацій. Раніше проведеними дослідженнями $[1,2,7,8]$ встановлено, що на просторову жорсткість проміжних скріплень типу КБ впливають, в основному, пружні характеристики амортизуючих прокладок i прикріплювачів клемних і закладних болтів.

Постановка проблеми. Однак при проведенні експериментальних робіт $[3,4,9]$ було встановлено, що в процесі експлуатації означені параметри можуть змінюватися в широкому діапазоні. Тому виникла необхідність спеціального вивчення цих процесів.

Основна частина. У цій статті наведені деякі результати експериментальних та теоретичних досліджень змін жорсткості скріплень при горизонтальному вигині i крученні рейок у процесі експлуатації. 
Жорсткість рейкових скріплень при горизонтальному вигині i крученні рейки можна подати у вигляді:

$$
\begin{gathered}
\mathrm{C}_{2}=\mathrm{U}_{\text {гшдн }}+\mathrm{U}_{\text {днуп }}+\mathrm{C}_{3}, \\
\mathrm{C}_{\varphi}=\frac{c_{\varphi 1} \cdot c_{\varphi 2}}{c_{\varphi 1}+c_{\varphi 2}}, \\
\mathrm{C}_{\varphi 1}=\frac{\mathrm{a}}{2} K_{\varphi}+\frac{\mathrm{a}^{2}}{8} K_{n}+\frac{a^{2}}{16} \mathrm{U}_{p \partial r}, \\
\mathrm{C}_{\varphi 2}=\frac{\mathrm{C}}{2} K_{n}+\frac{\mathrm{s}^{2}}{16} \mathrm{U}_{\text {шдрн }},
\end{gathered}
$$

де $\mathrm{C}_{z}$ - жорсткість скріплень при горизонтальному вигині рейки (горизонтальна жорсткість скріплення), кН/м;

$\mathrm{C}_{\varphi}-$ жорсткість скріплень при крученні рейки, кН·м/рад;

$\mathrm{C}_{\varphi 1}$ - жорсткість на крученні першої системи (клеми - підрейкова прокладка), кН·м/рад;

$\mathrm{C}_{\varphi 2}-$ жорсткість на крученні другої системи (закладні болти - нашпальна прокладка), кН·м/рад;

$\mathrm{U}_{\text {гшдн }}$ - динамічна жорсткість нашпальної прокладки на зсув, кН/м;

$\mathrm{U}_{\text {шдн }}$ - динамічна жорсткість нашпальної прокладки на стискання, кН/м;

$\mathrm{U}_{\text {днуп }}$ - динамічна жорсткість частини нашпальної прокладки, розташованої у викружці бетону, кН/м;

$\mathrm{U}_{\text {рдн }}$ - динамічна жорсткість підрейкової прокладки, кН/м;

$Ж_{п}-$ жорсткість пружинних шайб, кН/м;

$\mathrm{C}_{3}$ - жорсткість двох закладних болтів при зсуві підкладки, кН/м;

$K_{\varphi}-$ жорсткість клемного прикріплення при повороті рейки, кН·м/рад;

a - ширина підошви рейки, м;

в - ширина підкладки, м;

c - відстань між осями закладних болтів, м. як $[1,2]$

Параметри $\mathrm{U}_{\text {гшдн, }} \mathrm{C}_{3}$ та $\mathrm{K}_{\varphi}$ були розглянуті

$$
\begin{gathered}
\mathrm{U}_{\text {гшдн }}=\alpha_{1} \cdot \Delta \mathrm{y}^{\beta_{1}}, \\
\mathrm{C}_{3}=\alpha_{2} \cdot \mathrm{M}^{\beta_{2}}, \\
\mathrm{~K}_{\varphi}=\alpha_{3} \cdot \mathrm{M}^{\beta_{3}},
\end{gathered}
$$

де $\Delta y$ - величина стискання прокладки, мм;

$\mathrm{M}$ - момент закручування гайок болтів, $\mathrm{H} \cdot \mathrm{M}$; $\alpha_{\mathrm{i}}, \beta_{\mathrm{i}}-$ параметри формул.

3 урахуванням дій рухомого навантаження вказані залежності [1] були отримані у вигляді:

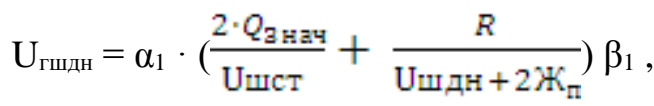

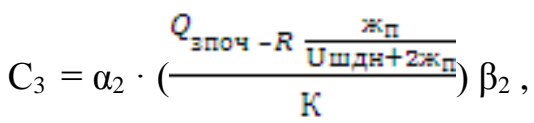

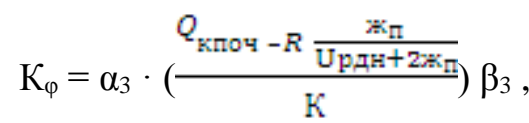

де $\mathrm{Q}_{\text {зпоч }}$ - початкове натягнення закладних болтів, $\mathrm{H}$;

$\mathrm{Q}_{\text {кпоч }}$ - початкове натягнення клемних болтів, $\mathrm{H}$;

Uшст - статична жорсткість нашпальних прокладок, кН/м;

К - коефіцієнт переходу від моменту закручування гайок до натягнення болтів. У середніх умовах $\mathrm{K}=136,5$;

$Ж_{n}$ - жорсткість пружніх шайб, кН/м;

$\mathrm{R}$ - вертикальна реакція рейкової опори, $\mathrm{H}$.

Параметри $\alpha_{2}, \alpha_{3}, \beta_{2}$ i $\beta_{3}$ визначені експериментально кафедрою «Колія та колійне господарство» для двовиткових пружних шайб поперечним перерізом $8 \times 10$ мм і $6 \times 10$ мм і наведені у табл. 1.

Параметри двовиткових пружних шайб

\begin{tabular}{|c|c|c|c|c|}
\hline Січення шайби & $\alpha_{2}$ & $\alpha_{3}$ & $\beta_{2}$ & $\beta_{3}$ \\
\hline $8 \times 10$ & 108,86 & 388,08 & 0,678 & 1,791 \\
\hline $6 \times 10$ & 116,47 & 80,10 & 0,741 & 2,697 \\
\hline
\end{tabular}


У процесі експлуатації відбуваються такі зміни жорсткостей пружних елементів, 3 яких складаються вказані жорсткості скріплення.

По-перше, відбувається послаблення натяжних гайок клемних і закладних болтів, що призводить до зменшення жорсткостей $\mathrm{C}_{z}$ i $\mathrm{C}_{\varphi}$. Процес послаблення натяжних гайок болтів був досліджений кафедрою «Колія та колійне господарство» УкрДАЗТ [2]. У результаті цих досліджень були встановлені залежності зменшення моменту закручування гайок клемних i закладних болтів у процесі експлуатації:

$$
\begin{aligned}
& \mathrm{M}_{3}=150-5,17 \mathrm{~T}^{0,775}, \\
& \mathrm{M}_{\mathrm{K}}=150-24,48 \mathrm{~T}^{0,560},
\end{aligned}
$$

де $\mathrm{M}_{\kappa}, \mathrm{M}_{3}$ - момент закручування гайок клемних та закладних болтів, Н·м;

$\mathrm{T}$ - пропущений тоннаж, млн т.

Початковий момент закручування гайок клемних і закладних болтів приймаємо рівним $150 \mathrm{H} \cdot \mathrm{M}$.

По-друге, у результаті старіння гуми виникає збільшення жорсткостей прокладок при їх стисканні і зсуві $[4,6]$.
Для визначення кількісних характеристик збільшення жорсткостей прокладок були проведені випробування за методикою, викладеною в [2]. Прокладки випробовувалися в спеціально створеному пристрої (рис. 1), який дає змогу проводити дослідження прокладок як на сумісну дію вертикальних і бокових сил, так і на дію тільки вертикальних сил. Дослідження проводилися на пульсуючому гідравлічному пресі ГРМ-2 при динамічному завантаженні. Частота прикладання навантаження $-11,5$ Гц, інтервал завантаження вертикальним навантаженням 40 - 80 кН, боковим - 30 - 60 кН.

Випробовувалися підрейкові прокладки типу ОП-143 і нашпальні типу ЦП-4 та ЦП-153, які були зняті при капітальному ремонті 3 однієї 3 ділянок колії металургійного підприємства. Вантажонапруженість ділянки складала 30 млн ткм/км брутто за рік, перебування у колії - 18 років.

У результаті випробувань було встановлено, що вказані жорсткості прокладок типу ЦП-4 збільшились на $27 \%$, ЦП-153 на $20 \%$, у порівнянні з визначеними раніше у [3].

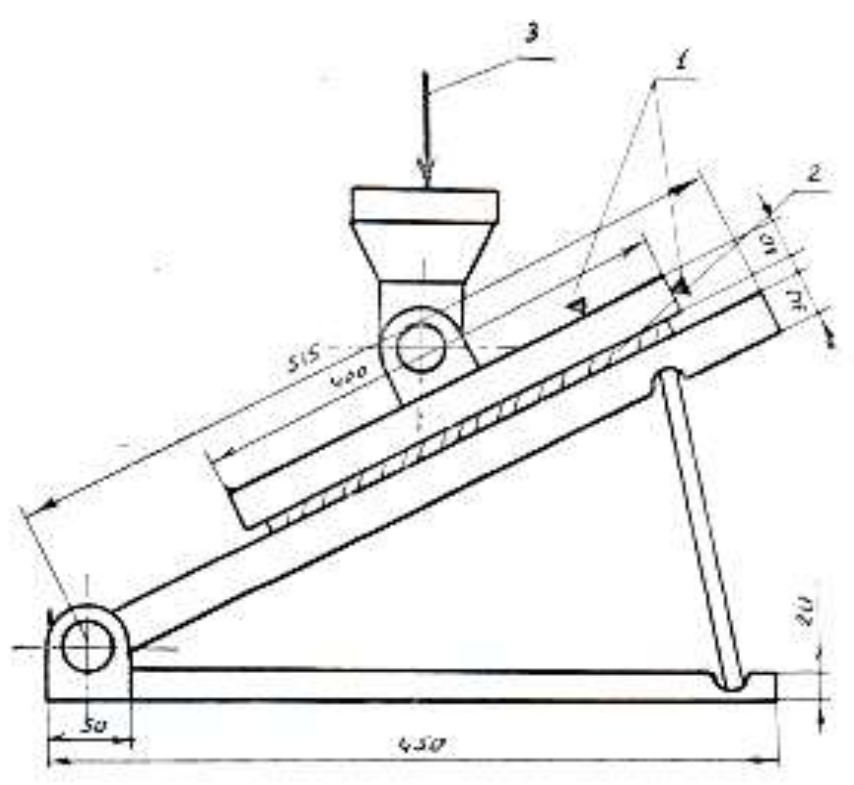

Рис. 1. Схема устаткування для динамічних досліджень прокладок:

1 - електропрогиноміри; 2 - прокладка; 3 - динамічне навантаження

У роботі [4] відмічено, що основний фактор, який впливає на старіння гуми - час іiі служби. Таким чином, допускаючи лінійну залежність збільшення жорсткостей прокладки від терміну їх служби, можна встановити жорсткості прокладок у процесі експлуатації.

$\mathrm{У}$ табл. 2 наведені орієнтовні залежності збільшення жорсткостей прокладки від часу їх служби. 
Залежність жорсткості від строку служби прокладок

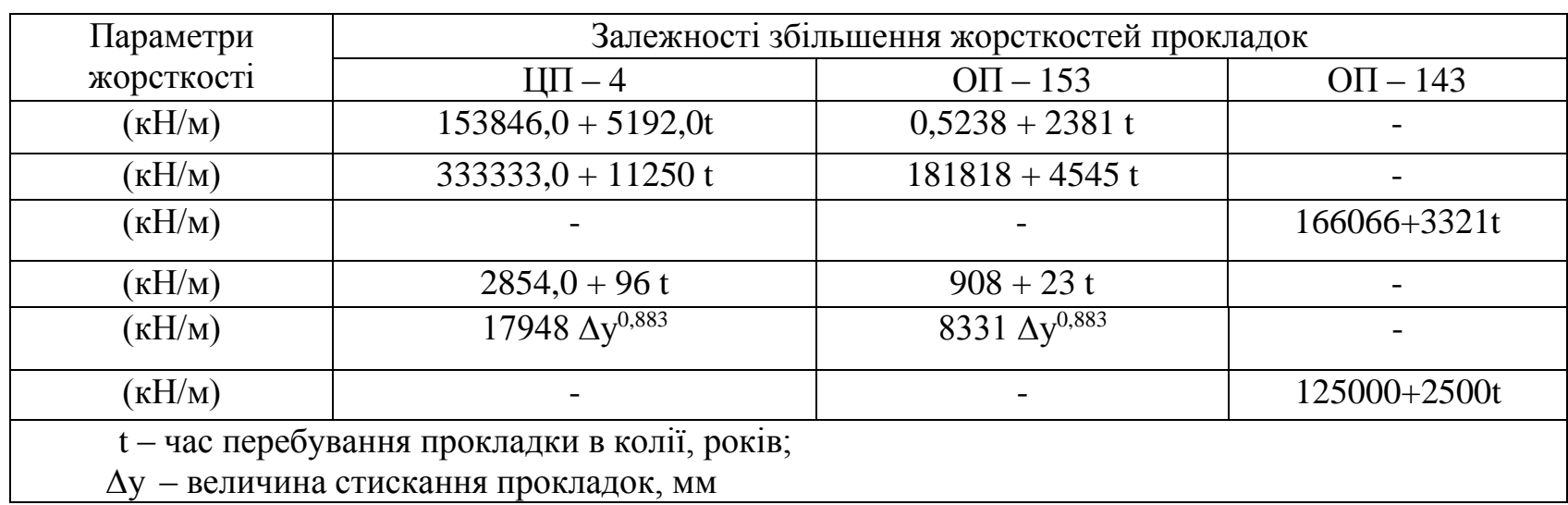

Розрахунок жорсткостей рейкових скріплень у процесі експлуатації виконаний за формулами (1) - (6). При розрахунку були прийняті такі допущення:

1. Початковий момент закручування гайок клемних i закладних болтів прирівнюється до $150 \mathrm{H} \cdot \mathrm{м}$.

2. У процесі експлуатації момент закручування гайок болтів зменшується до нуля за залежностями (10), (11).

3. Пропонується лінійна залежність збільшення жорсткостей гумових прокладок за формулами, наведеними у табл. 2.
Розрахунок жорсткостей скріплень типу КБ при горизонтальному вигині i крученні рейки був виконаний для двох варіантів. Перший варіант - підрейкова прокладка типу ЦП-5 (кордоніт), нашпальна прокладка типу

ЦП-4 (7 мм). Другий варіант - підрейкова прокладка типу ЦП-143 нашпальна прокладка типу ОП-153 (10 мм). Пружинні шайби в обох випадках прийняті перерізом $8 \times$ 10 мм.

Результати розрахунків наведені в табл. 3 та 4 і графічно на рис. $2-4$.

Таблиця 3

Жорсткість рейкових скріплень при горизонтальному вигині рейки

\begin{tabular}{|c|c|c|}
\hline Термін служби, років & \multicolumn{2}{|c|}{$\mathrm{C}_{\mathrm{z}}, \mathbf{\kappa \mathrm { H }} / \mathrm{M}$} \\
\cline { 2 - 3 } & I вар. & II вар. \\
\hline 0 & 58704 & 50955 \\
\hline 2 & 31446 & 24560 \\
\hline 4 & 18084 & 11844 \\
\hline 6 & 10583 & 4977 \\
\hline 8 & 8225 & 3184 \\
\hline 16 & 59115 & 51583 \\
\hline 18 & 31716 & 24872 \\
\hline
\end{tabular}

Жорсткість рейкових скріплень при крученні рейки

Таблиця 4

\begin{tabular}{|c|c|c|}
\hline \multirow{2}{*}{ Пропущений тоннаж, млн т } & \multicolumn{2}{|c|}{$\mathrm{C}_{\varphi}, \mathrm{\kappa H} \cdot \mathrm{M} / \mathrm{pa}$. } \\
\cline { 2 - 3 } & I вар. & II вар. \\
\hline 2 & 889,0 & 289,2 \\
8 & 879,3 & 277,3 \\
16 & 882,7 & 280,5 \\
525 & 974,3 & 395,1 \\
\hline
\end{tabular}


Інтервал часу, в якому визначались жорсткості скріплень, визначався із умов повного послаблення клемних (для $\mathrm{C}_{\varphi}$ ) $\mathrm{i}$ закладних (для $\mathrm{C}_{z}$ ) болтів. Для закладних болтів цей час, який визначається із залежностей (11), (12), отримали 2 роки.

a)

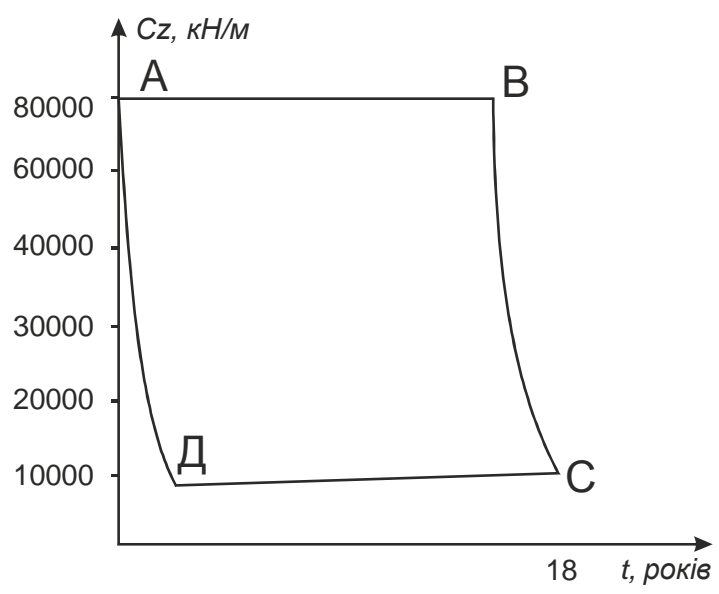

На рис. 2-3 наведені графіки зміни жорсткостей скріплення типу КБ при горизонтальному вигині i крученні рейок. Крива АД відповідає зміні жорсткостей рейкових скріплень типу КБ в початковий період експлуатації до повного послаблення натягнення закладних болтів.

б)

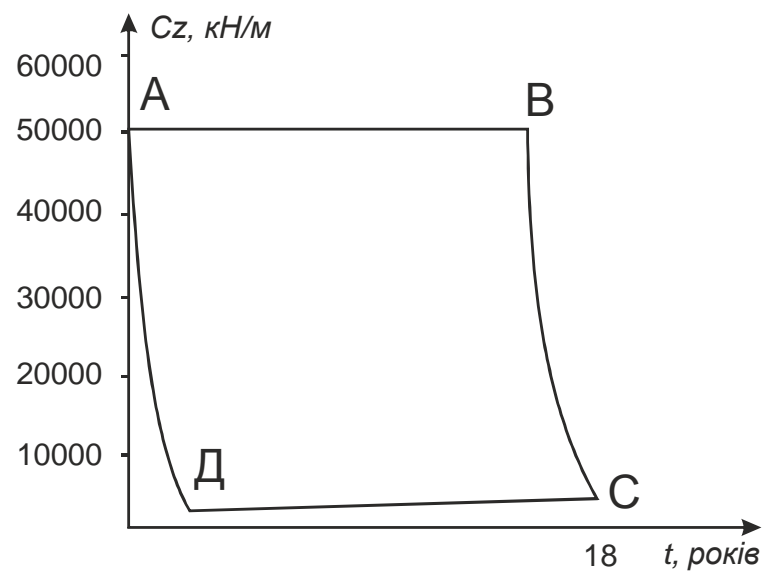

Рис. 2. Зміна горизонтальної жорсткості скріплень типу КБ:

a - при прокладках типу ЦП-4 та ЦП-5; б - при прокладках типу ЦП-143 та ЦП-153

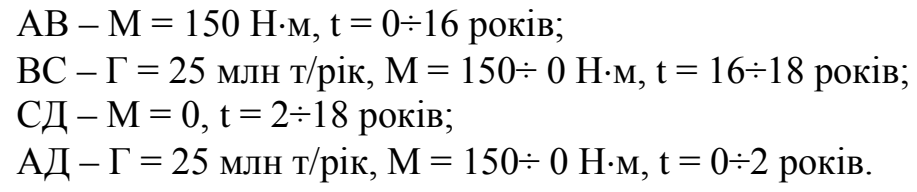

a)

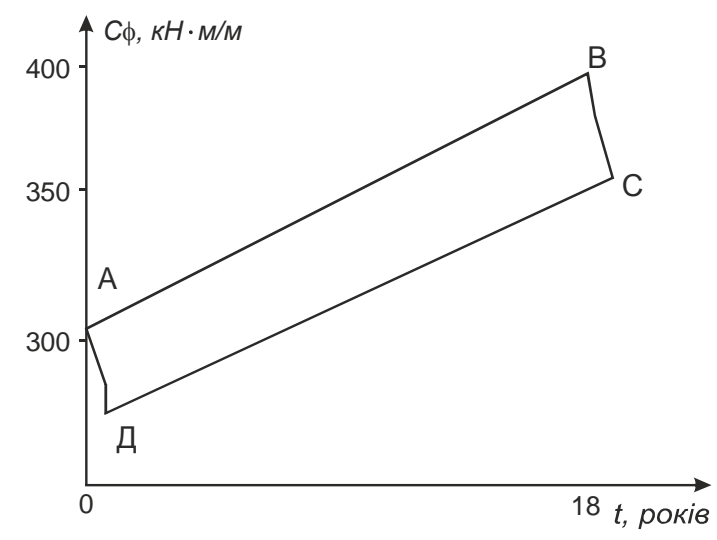

б)

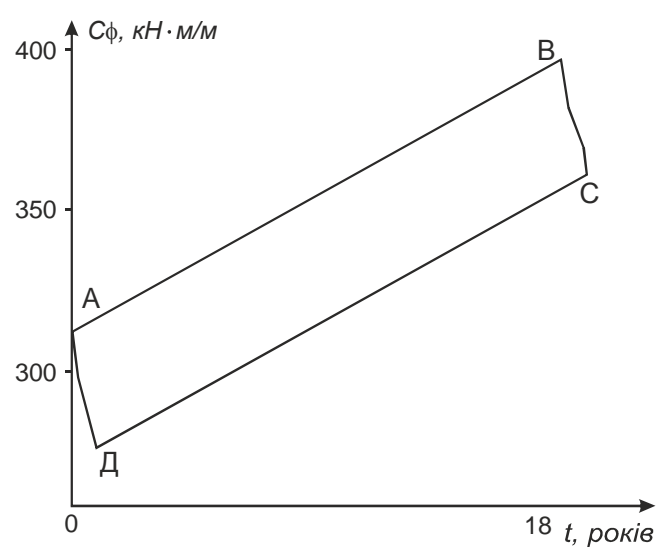

Рис. 3. Зміна жорсткості скріплень типу КБ:

a - при прокладках типу ЦП-4 та ЦП-5; б - при прокладках типу ЦП-143 та ЦП-153

$$
\begin{aligned}
& \mathrm{AB}-\mathrm{M}=150 \mathrm{H} \cdot \mathrm{M}, \mathrm{t}=0 \div 16 \text { років; } \\
& \mathrm{BC}-\mathrm{M}=150 \div 0 \mathrm{H} \cdot \mathrm{M}, \mathrm{t}=0 \div 18 \text { років; } \\
& \text { СД }-\Gamma=25 \text { млн т/рік, } \mathrm{M}=0, \mathrm{~T}=2-18 \text { млн т. } \\
& \text { АД }-\mathrm{M}=150 \div 0 \mathrm{H} \cdot \mathrm{M}, \mathrm{t}=0 \div 2 \text { років. }
\end{aligned}
$$


Пряма СД - зміна жорсткості при повністю послаблених болтах за час 2-18 років.

Пряма $\mathrm{AB}$ - зміна жорсткостей скріплень при постійному моменті закручування гайок болтів, рівному $150 \mathrm{H} \cdot \mathrm{м}$ за час 2-16 років.

Крива ВС - зміна жорсткостей після експлуатації терміном 16 років. Момент закручування гайок болтів змінюється від $150 \mathrm{H} \cdot \mathbf{м}$ до 0.

a)

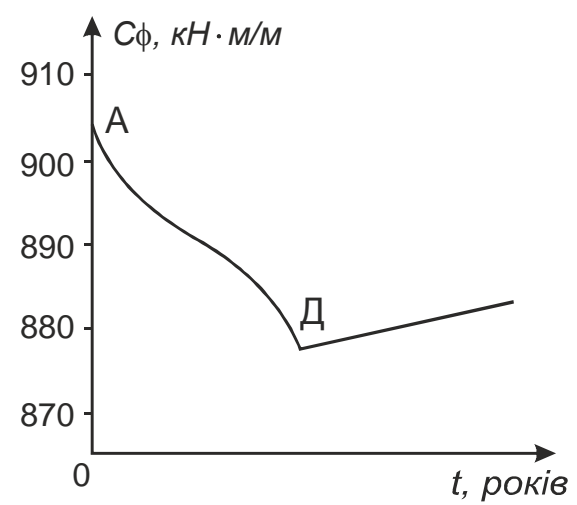

Таким чином, поле графіка, обмежене фігурою АВСД, відповідає всім можливим змінам жорсткості $C_{z}, C_{\varphi}$ за час експлуатації 0-18 років.

На рис. 4 наведені більш докладно графіки зміни жорсткості скріплень при крученні рейок у початковий період експлуатації (0-2 років).

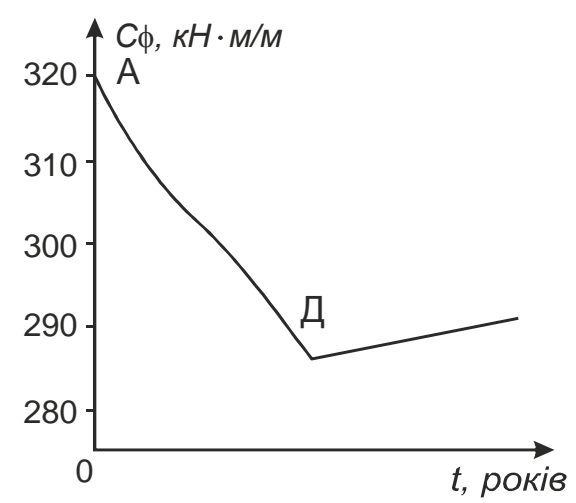

Рис. 4. Зміна жорсткості скріплень на кручення в початковий період експлуатації: a - при прокладках типу ЦП-4 та ЦП-5; б - при прокладках типу ЦП-143 та ЦП-153

\section{Висновки:}

1. У початковий період експлуатації ( $\mathrm{T}=0-2$ років) горизонтальна жорсткість скріплень типу КБ зменшується від 58704 до 8225 кН/м при прокладках ЦП-4 та ЦП-5. При прокладках ОП-143 та ОП-153 цей параметр зменшується від 50955 до 3184 кН/м. Момент закручування гайок закладних болтів змінюється при цьому від $150 \mathrm{H} \cdot$ м до 0.

2. Після терміну служби цей параметр змінюється у таких межах: при прокладках ЦП4 та ЦП-5 від 59115 до 8297 кН/м; при прокладках ОП-143 та ОП-153 - 51583 до 3949 кН/м.

3. Приблизно $85 \%$ горизонтальної жорсткості скріплень забезпечується за рахунок жорсткості закладних болтів при зсуванні підкладки. Цей висновок зроблений в [6], де жорсткість закладних болтів включена в параметр «Жорсткість бокового упору».

4. У початковий період експлуатації $(\mathrm{t}=0-2$ років) жорсткість скріплень при крученні рейки змінюється в таких межах: при прокладках ЦП-4 та ЦП-5 С ${ }_{\varphi}=904,4 \div 878,5$ кН·м /рад; при прокладках ОП-143 та ОП-153 $\mathrm{C}_{\varphi}=312,0 \div 276,5$ кН·м/рад. Момент закручування клемних болтів змінюється від $150 \mathrm{H} \cdot \mathrm{M}$ до 0.

5. Після терміну служби 16 років величина $\mathrm{C}_{\varphi}$ змінюється в межах:

а) при прокладках ЦП-4 та ЦП-5 від 974,8 до 941,9 кН·м/рад;

б) при прокладках ОП-143 та ОП-153 від 395,1 до 359,7 кН·м/рад.

6. Приблизно $80 \%$ жорсткості рейкових скріплень при крученні рейок забезпечується за рахунок жорсткості прокладок.

\section{Список використаних джерел}

1. Даренський, О.М. Математична модель просторової жорсткості скріплення типу КБ [Текст] / О.М. Даренський // Зб. наук. праць. - Харків: УкрДАЗТ, 2007. - Вип. 80. - С. 166-176.

2. Оценка надежности работы промежуточных скреплений типа КБ в условиях железных дорог металлургических предприятий [Текст] / ІКСЗТ. - 2006. - № 4. -С. 23-25. 
3. Даренський, О.М. Експериментальне визначення пружних характеристик прокладок проміжного скріплення КБ [Текст] / О.М. Даренський, В.Г. Витольберг // Зб. наук. праць. - Харків: УкрДАЗТ, 2007. - Вип 87. - С. 172-178.

4. Григорьев, Е.Т. Расчет и конструирование резинових амортизаторов [Текст] / Е.Т. Григорьев. - М.: Машиностроение, 1960.

5. Железобетонные шпалы для рельсового пути [Текст] / А.Ф. Золотарский, Б.А. Евдокимов, Л.Г. Исаев, Л.Г. Крысанов [и др.]; под ред. А Ф. Золотарского. - М.: Транспорт, 1980. - 270 с.

6. Шахунянц, Г.М. Работа болтов в скреплениях [Текст] / Г.М. Шахунянц, А.А. Контратьев // Труды МИИТ. - М.: МИИТ, 1973. - Вып. 362. - С. 34-45.

7. Даниленко, Е.І. Правила розрахунків залізничної колії на міцність і стійкість (ЦП-0117) [Текст] / Е.І. Даниленко, В.В. Рибкін. - К.: Транспорт України, 2006. - 168 с.

8. Даренский, А.Н. Результаты лабораторных испытаний скрепления типа КБ [Текст] / А.Н. Даренський. - Харьков: ХИИТ, 1983. - Деп. в ЦНИИТЭИ МПС 18.03.83, № 2145.

9. Дар енський, О.М. Экспериментальное определение сопротивлений скреплений КБ и КПП 5 перемещениям рельсов в продольной плоскости [Текст] / О.М. Даренський, В.Г. Вітольберг // Зб. наук. праць. - Донецьк: ДонНИИЖТ 2008. - № 15. - С. 112-124.

\section{Рецензент д-р техн. наук, професор О.М. Даренський}

Вітольберг Володимир Геннадійович, канд. техн. наук, доцент кафедри колії та колійного господарства

Української державної академії залізничного транспорту. Тел.: 730-10-60.

Рева Володимир Миколайович, магістрант ІППК. Тел.: (099) 928-81-31.

Vitolberg Vladimir Gennadievich, cand. of techn. sciences Department "Road and track acilities" Ukraine State of Railway Transport Tel .:(057) 730-10-60.

Reva Volodimyr Mykolajovych, Master Training Institute. Tel: (099) 928-81-31. 